\title{
Effects of Anxiety and Learning Styles on Foreign Language Testing: Case of Work-Study Contract Students
}

\author{
Karine Longis McMillan \\ at EFIATP, France \\ karinelmcmillan@gmail.com
}

\begin{abstract}
Studies have proved multiple times that anxiety and different learning styles within the FL classroom affect students when they are doing a test. These studies however have not yet observed every different kind of students. With this context, data were collected from 7l workstudy contract vocational higher diploma students from EFIATP Correze, France during the 20202021 academic years. As a conclusion of this study, it is determined that there are no significant relationships between the FL student anxiety in the classroom, their learning styles and their test Level.
\end{abstract}

Keywords: FL, foreign language, anxiety, learning styles, test level, work-study contract students.

Received 27 April 202I/Accepted 18 August 202I CAuthor all rights reserved

\section{Introduction}

Learning a foreign language is essential in a globalized world and therefore all learners in the French school system have to take English as a foreign language classes. Some learners, however, have more difficulty learning and performing in the target language than others (Horwitz, Horwitz \& Cope, 1986). Moreover, in its 2012 annual report, the TOEFL (Test of English as a Foreign Language) notes that France is among the worst students in foreign language learning in the world. To explain this situation, several studies (Ayalp \& Özdemir, 2016) have studied differences in learning style, an important factor affecting learner success as tested through punctual exams, while others (Young, 1986; Gardner et al., 1987) have focused on the anxiety felt by some learners in language classrooms. Indeed, it is regularly mentioned in the literature that learners have different learning styles, which plays an important role in the learning process (Cano, 1999; Cano \& Garton, 1994; Moussa, 2014) and that anxiety has a negative effect on student success (Burns, 2004; Cassady \& Johnson, 2002; Rana \& Mahmood, 20I0; Von Der Embse, Schultz, \& Draughn, 20I5). 
However, by looking at these studies, we realized that they were limited and showed an existing gap since, first of all, none of them linked together testing results, learning styles and language anxiety and, second of all, none of them were unique to French students and in particular workstudy contract students. The direct impact of failing to address these subjects together can impact the students academically as well as other areas of their lives.

This research will examine what effective learning styles look like, what levels of anxiety are acceptable, and what effective mix of learning strategies and anxiety levels are needed to get the best testing results. This research will provide more strategies that can be implemented in the schools to support French work-study students learning English. Through this study, we will seek to better understand the links that may exist between the testing results of our specific French audience, their different learning styles and the language anxiety they may experience in English classes. To do so, we will begin by reviewing the literature and then we will introduce the issue raised. We will then present the method used to answer our questions. Finally, we will end with a discussion of the results obtained and the analysis that it will have caused.

\section{Literatur review}

According to the literature, there is a wide variety of correlates with foreign language achievement. Some variables are studied individually, while others are studied together. Thus, according to authors like Onwuegbuzie, Bailey \& Daley (1999), there are confirmed correlations between various learning styles and language anxiety.

\section{Learning styles}

Even though there is no single definition for learning styles that is commonly accepted by all (Deveci, 2013), the literature has produced various definitions that focus on individual learning, personality or learner preferences (Dunn, 1984; Joy \& Kolb, 2009; Hariri \& Seadatee Shamir, 20I4; Hawk \& Shah, 2007). For Claxton \& Ralston (1978) for example, learning style is the regular way a student responds to stimuli and uses them in the course of learning whereas for other authors, learning styles are a characteristic, personal and distinct way of acting and behaving in a learning environment (Chevrier et al., 2000). For others (Dunn \& Dunn, 1993) learning styles are the way each learner begins to focus, process and retain new and difficult information. In short, the learning style is the usual way in which one prefers to acquire, process and store new information" (Cesur \& 
Fer, 2009, p. 290) and it consists of distinctive behaviors used as indicators of how a person learns from and adapts to his or her environment. "It also provides clues about how a person's mind works" (Gregorc, 1979, p. 234). Characteristics of learning styles that allow for individualized instruction (Dunn, DeBello, Brennan, Krimsky \& Murrain, 198I) are used to understand how learners receive information in different ways (Chun-Shih \& Gamon, 2002) and help the learning process unfold in a systematic way.

To this end, knowing about the learner's learning style can allow him or her to develop strategies and to try correct what is lacking and/or to achieve good results (Butler, 1987).

\section{Anxiety}

According to (Barlow, 2002), anxiety is a state of purposeless preoccupation. According to Macintyre and Gardner (1994), with foreign languages learning, anxiety is a feeling of tension and fears unambiguously associated speaking, listening, reading, writing and learning in a different language. Williams identifies anxiety in the foreign language classroom as "a response to a condition in which an external element is perceived to present a demand that may exceed the learner's abilities and resources to meet it" (Williams 1991: 25). Various research on language anxiety demonstrates a negative impact on language learning (Young, 1986) and shows that it affects learners in negative cognitive, sensual and behavioral ways (Barrows, Dunn \& Lloyd, 20I3; Cassady \& Johnson, 2002; Chapell, Blanding, Silverstein, Takahashi, Newman, Gubi \& McCann, 2005; Rana \& Mahmood, 2010). The perception of this threat results in a psychological emotion and/or physiological reaction that interfere with the learner's concentration, attention and effort by preventing him or her from mastering the assigned task. Eysenck (1979) however states that, though anxiety causes negative thoughts that divide cognitive resources and consequently hamper learning, the anxious student will repeatedly try to compensate by increasing the determination assigned to the task. So, even though Horwitz et al. (1986) state that over studying can be a source of anxiety, this feeling can also be beneficial because, in the face of their anxiety, some learners put in greater effort that will lead them to success (Wilkinson, 20 I I; Kleinmank, 1977). 
Much more than simply assigning labels, we believe that increased knowledge of learners' different learning styles and anxiety should be used to question and explain preferences and ways of doing things that are common in learning and success in foreign language learning.

\section{Research Questions}

Several factors seem to influence the success of an ESL learner. We will here in particular focus on two factors that may play a role in succeeding during class assessment: the learning style and the language anxiety. In other words, in this study, we argue that the learning style of our specific population and/or their English language anxieties influence their success in ESL classes.

To achieve the goal of this study, the following research questions were addressed:

- What are the main learning styles specific to our population, Higher Vocational Diploma students, majoring in Public Works through a work-study contract?

- Is there a significant correlation between the learning styles specific to our population and their success?

- What is the level of anxiety of these learners according to the FLCAS instrument?

- Is there a significant correlation between our population's English language anxiety and their success?

The results of this study will be useful in supporting the pedagogical practice of English language teachers working with these groups of learners, especially those teaching learners who are often expected to be anxious. The study also provides additional insights and knowledge to the existing literature on anxiety with foreign language learning. Furthermore, to our knowledge, no empirical study has ever examined learning styles and foreign language anxiety in a French context of Higher Vocational Diploma students, majoring in Public Works through a work-study contract.

\section{linstitution}

I have been teaching at the EFIATP Public Works vocational school in Egletons since 20I5. This establishment, which hosts several training courses ranging from vocational certificates to 
vocational degrees, specializes in the field of public works. It welcomes about 500 students from all over France and sometimes even from outside of France.

One of the school main philosophies has particularly caught our attention: "Teaching for successful students". More specifically, this study allowed us to reflect on the different means to be put in place to reduce the dropout rate and the lack of motivation of certain learners in LVI English classes. By studying the impacts of learning styles and language anxiety on learner success, our objective is to find the tools to be put in place to create a work climate conducive to everyone's development and to make the English class a place where everyone finds their place.

\section{Method}

\section{Participants}

In this context, the working sample of our study is composed of 4 classes of French-speaking learners studying for their higher vocational Diploma, majoring in Public Works through workstudy contracts at the private training school EFIATP, France during the school year 2020-202I.

The learners $(N=7 I)$ are aged 18 to $23(M=19.10, S D=1.13)$ over the two years, with respectively 40 learners in the Ist year $(M=18.63, S D=.92)$ and 31 in the 2 nd year $(M=\mid 9.71$, $\mathrm{SD}=1.10$ ). Our population is composed of 69 men and 2 women, the women being both in 2 nd year. For our study, it is important to specify that all learners have English as their first foreign language and none of them come from an English-speaking family. According to the descriptors of the Common European Framework of Reference for Languages (CEFRL), the general level in English of the 4 classes is heterogeneous and ranges from $\mathrm{A} 2$ to $\mathrm{BI}$ in English as a foreign language.

The surveys were administered online in conjunction with an informed consent form via e-mail. The informed consent form explained to the participants the nature of the study, informed them of the confidentiality of their responses and notified them of any risk. Since the surveys were online, students were asked to indicate their consent electronically instead. 


\section{Material and Procedure}

The study therefore seeks to understand whether students' levels of anxiety or learning styles impact their success during an assessment in English class. To do so, two questionnaires were used: the FLCAS to study anxiety and the LSQ-Fa to study learning styles. The success rate was assessed using a JETSET-type assessment.

Learners' learning styles were observed using the Learning Style Questionnaire (LSQ) instrument by Honey and Mumford (1986), and more specifically its adapted French version, the LSQ-FA (Théberge, Chevrier, Fortin \& Leblanc, 2000). This instrument establishes a static model for each learner according to four learning styles: active, reflective, theoretical and pragmatic. The LSQ-Fa remains identical to the LSQ-F in its purpose and structure, retaining the format of the seven-point Likert response scale. However, it differs in the length of the 4 scales, each one going from 20 to 12 items. Examples of items are "Tout comptefait, j'écoute plus que je ne parle (Translated from French: In the end, I listen more than I speak)" and "J'aime beaucoup essayer de nouvelles choses pour voirsielles fonctionnent dans la pratique (Translated from French: I like to try new things to see if they work in a practical manner). The score on one scale therefore varies from 12 to 84 points. The LSQ-Fa thus seeks to highlight preferences in the way of learning. The questionnaire was distributed to the learners while we reminded them that this study had no relation to their current English course but rather to their learning styles in general.

In addition, for this study, the FLCAS (Foreign Language Classroom Anxiety Scale) questionnaire was distributed to all learners. In order to ensure that all participants understood the questionnaire in its entirety, we kept the 33 items proposed by the original version of Horwitz et al. (1986) but used the French version validated by Ferris (2016). Examples of items are "Je me sensconfiant(e) lorsque je parleanglais (Tranlated from French: I am confident when I speak English)” and “Celam'effraiequand je ne comprends pas ce que le professeur ditenanglais (Translated from French: I am afraid when I don't understand what the teacher is saying in English)". For each item, the learner had to choose between 5 answers: "really agree", "agree", "neutral", "disagree", "really disagree". The answers correspond to a Likert scale of I to 5 points. The most anxious learners thus had a higher score than the least anxious learners. 
Finally, to evaluate their success in English as a foreign language, JETSET-type listening assessments adapted to their level were used. The assessment consisted of three MCQ listening exercises ranging from the easiest to the most difficult and lasting about 20 minutes.

The FLCAS questionnaire is composed of 33 items to which I to 5 points are attributed, the maximum score is 165 points and corresponds to a very high level of anxiety and the minimum score is 33 points, which illustrates a low level of language anxiety. The value for Cronbach's Alpha for the survey is $\alpha=.795$. Both Ist and 2 nd year learners generally have low anxiety. $2^{\text {nd }}$ year learners are slightly more anxious than the $I^{\text {st }}$ year learners. Here is the table summarizing the results obtained:

Table I

Level of anxiety in English class for the French-speaking learners studying for their higher vocational Diploma, majoring in Public Works through work-study contracts

\begin{tabular}{cccccccccc}
\hline & \multicolumn{3}{c}{ Ist year } & \multicolumn{3}{c}{$2^{\text {2dyear }}$} & \multicolumn{3}{c}{ Total } \\
\hline & $\mathrm{N}$ & Mean & SD & $\mathrm{N}$ & Mean & SD & $\mathrm{N}$ & Mean & SD \\
\hline All & 40 & 93.95 & $12.8 \mathrm{I}$ & $3 \mathrm{I}$ & 97.70 & 12.93 & 71 & 95.59 & $12.9 \mathrm{I}$ \\
Low anxiety & 26 & 86.23 & 7.58 & 16 & 87.43 & 8.22 & 42 & 86.69 & 7.75 \\
High anxiety & 14 & 106.00 & 6.42 & 15 & 108.66 & 6.06 & 29 & 108.48 & 6.13 \\
\hline
\end{tabular}

The LSQ-FA learning style questionnaire allows you to assign from 12 to 84 points per style. The value for Cronbach's Alpha for the survey is $\alpha=.870$. The learners generally demonstrate using more the reflective style and less the active style. Here is the table summarizing the results obtained: 
Table 2

Points in each category of learning styles for the French-speaking learners studying for their higher vocational Diploma, majoring in Public Works through work-study contracts

\begin{tabular}{cccccccccc}
\hline & \multicolumn{3}{c}{ Ist year } & \multicolumn{2}{c}{$2^{\text {ndyear }}$} & \multicolumn{3}{c}{ Total } \\
\hline & $\mathrm{N}$ & Mean & SD & $\mathrm{N}$ & Mean & SD & $\mathrm{N}$ & Mean & SD \\
\hline Active style & 40 & 43.92 & 6.39 & 31 & 42.48 & 6.27 & 71 & 43.29 & 6.33 \\
Reflective style & 40 & 65.95 & 8.92 & 31 & 66.96 & 8.09 & 71 & 66.39 & 8.52 \\
Theorical style & 40 & 58.55 & 10.03 & 31 & 57.61 & 7.78 & 71 & 58.14 & 9.07 \\
Pragmatic style & 40 & 58.97 & 10.39 & 31 & 58.32 & 8.42 & 71 & 58.69 & 9.52 \\
\hline
\end{tabular}

The assessment of the learners' competency level in English as a foreign language was done with one JETSET-type listening assessment graded out of 30 points with 30 being the best possible score. The results collected show that the scores remains average with the $I^{\text {st }}$ year having a slightly better. Here is the table summarizing the results:

Table 3

Assessment results out of 30 for the French-speaking learners studying for their higher vocational Diploma, majoring in Public Works through work-study contracts

\begin{tabular}{cccccc}
\hline & \multicolumn{5}{c}{ Total } \\
\hline & $\mathrm{N}$ & Min & Max & Mean & SD \\
\hline $\begin{array}{c}\text { Assessment } \\
\text { results }\end{array}$ & 7I & 3.00 & 25.00 & 16.43 & 3.95 \\
& & & & &
\end{tabular}

Table 4

Assessment results out of 30 for the French-speaking learners studying for their English

\begin{tabular}{ccccccccccc}
\hline & \multicolumn{1}{c}{ Ist year } & \multicolumn{1}{c}{$2^{\text {ndyear }}$} \\
\hline & $\mathrm{N}$ & Min & Max & Mean & SD & N & Min & Max & Mean & SD \\
\hline $\begin{array}{c}\text { Assessment } \\
\text { results }\end{array}$ & 40 & 11.00 & 23.00 & 17.35 & 2.86 & 31 & 3.00 & 25.00 & 15.25 & 4.83 \\
\hline
\end{tabular}




\section{Data Analysis}

After collecting of the quantitative data from the surveys on language anxiety and learning styles as well as collecting the test results, it is reviewed, and a descriptive analysis is done. Pearson correlation statistic was used to test the hypothesis.

\section{Result}

After observing all of the students' data through the descriptive analysis, we decided to examine the correlations between the variables of our hypothesis: the learning style, the language anxiety and language test results. We argue that the learning style of our specific population and/or their English language anxieties influence their success in ESL classes.

The analysis of the data between the population's different learning styles and the test results shows that there is no significant relationship. Here is the table summarizing the results:

Table 4

Correlations between the learner's different learning styles and test results.

\begin{tabular}{|c|c|c|c|c|c|}
\hline $\begin{array}{l}\text { Test } \\
\text { results }\end{array}$ & $\begin{array}{c}\text { Test } \\
\text { results } \\
.\end{array}$ & $\begin{array}{l}\text { Active } \\
\text { style }\end{array}$ & $\begin{array}{l}\text { Reflective } \\
\text { style }\end{array}$ & $\begin{array}{c}\text { Theoretical } \\
\text { style }\end{array}$ & $\begin{array}{c}\text { Pragmatic } \\
\text { style }\end{array}$ \\
\hline $\begin{array}{l}\text { Active } \\
\text { style }\end{array}$ & -.026 & . & & & \\
\hline $\begin{array}{l}\text { Reflective } \\
\text { style }\end{array}$ & .227 & .213 & . & & \\
\hline $\begin{array}{l}\text { Theoretical } \\
\text { style }\end{array}$ & .124 & $.277^{*}$ & $.402 * *$ & . & \\
\hline $\begin{array}{l}\text { Pragmatic } \\
\text { style }\end{array}$ & .006 & $.379 * *$ & $.355^{* *}$ & $.676 * *$ & . \\
\hline
\end{tabular}


Due to the lack of correlations between the different learning styles and the general test results, we looked into the correlations according to the learners' different school years. These analyses however show no significant correlation. Here are the tables summarizing the results:

Table 5

Correlations between the Ist year learner's different learning styles and test results.

\begin{tabular}{lccccc}
\hline & $\begin{array}{c}\mathrm{I}^{\text {st}} \text { yearTest } \\
\text { results }\end{array}$ & $\begin{array}{c}\text { Active } \\
\text { style }\end{array}$ & $\begin{array}{c}\text { Reflective } \\
\text { style }\end{array}$ & $\begin{array}{c}\text { Theoretical } \\
\text { style }\end{array}$ & $\begin{array}{c}\text { Pragmatic } \\
\text { style }\end{array}$ \\
\hline $\begin{array}{l}\mathrm{I}^{\text {styear }} \text { - Test } \\
\text { results }\end{array}$ &. & & & & \\
\hline Active style & .066 &. & & & \\
Reflective style & .220 & .260 &. &. & \\
Theoretical style & .188 & $.422^{* *}$ & $.422^{* *}$ & $.684^{* *}$ &. \\
Pragmatic style & .116 & $.382^{*}$ & $.318^{*}$ & & \\
\hline
\end{tabular}

*. Correlation is significant at the 0.05 level (2-tailed)

**. Correlation is significant at the 0.01 level (2-tailed)

Table 6

Correlations between the $2^{\text {nd }}$ year learner's different learning styles and test results.

\begin{tabular}{|c|c|c|c|c|c|}
\hline & $2^{\text {ndyearTest }}$ results & Active style & Reflective style & Theoretical style & Pragmatic style \\
\hline $2^{\text {nd }}-$ Test results & . & & & & \\
\hline Active style & -.160 & . & & & \\
\hline Reflective style & .302 & .166 & . & & \\
\hline Theoretical style & .059 & .025 & $.38 I^{*}$ & . & \\
\hline Pragmatic style & -.116 & $.375^{*}$ & $.429 *$ & $.657^{* *}$ & . \\
\hline
\end{tabular}

The analysis of the data between the population's language anxiety and the test results shows that there is no significant relationship. Here is the table summarizing the results:

Table 7

Correlations between the learner's language anxiety and test results.

\begin{tabular}{lccc}
\hline & Language anxiety & Low Language Anxiety & High Language Anxiety \\
\hline Test results & .129 & -.143 & .269 \\
\hline *. Correlation is significant at the 0.05 level (2-tailed) $* *$ Correlation is significant at the 0.01 level (2-tailed)
\end{tabular}


Due to the lack of correlations between the language anxiety and the general test results, we looked into the correlations according to the learners' different school years. These analyses however show no significant correlation. Here are the tables summarizing the results:

Table 8

Correlations between the Ist year learner's language anxiety (general, low and high) and test results.

\begin{tabular}{lccc}
\hline $\begin{array}{c}\text { Language } \\
\text { anxiety }\end{array}$ & $\begin{array}{c}\text { Low Language } \\
\text { Anxiety }\end{array}$ & $\begin{array}{c}\text { High Language } \\
\text { Anxiety }\end{array}$ \\
\hline |st - Test results & $.09 \mid$ & -.072 & -.164 \\
\hline *. Correlation is significant at the 0.05 level (2-tailed) & & \\
**. Correlation is significant at the 0.01 level (2-tailed) & &
\end{tabular}

Table 9

Correlations between the $2^{\text {nd }}$ year learner's language anxiety (general, low and high) and test results.

\begin{tabular}{lccc}
\hline & $\begin{array}{c}\text { Language } \\
\text { anxiety }\end{array}$ & Low Language Anxiety & High Language Anxiety \\
\hline $2^{\text {nd }}-$ Test results & .250 & -.400 & .098 \\
\hline *. Correlation is significant at the 0.05 level (2-tailed) & & \\
**. Correlation is significant at the 0.01 level (2-tailed) &
\end{tabular}

Since there is no relationship between our variables, our results are not in agreement with the literature (Josse, 2007; Maclntyre \& Gardner, 1994; Wilkinson, 20II; Zheng, 2008; Kleinmank, 1977; Chastain, 1975).More specifically, no correlation was found between learning styles and test results nor between the anxiety levels (in general, low and/or high) and the test results. We also looked for any possible relationship between the anxiety felt by our learners and their learning styles, however, no correlation was found either. We can therefore only observe and comment on the different results individually, but in no way claim that these variables are related to the performance or to each other. 


\section{Discussion}

The main goal of our study was to analyze the influence of our specific population's learning styles or anxieties in English on their assessment results in English classes. The first step was to discover the main learning styles specific to our population, French-speaking learners studying for their higher vocational Diploma, majoring in Public Works through work-study contracts. The second step was to find out if there was a significant correlation between the learning styles specific to our population and their English assessment results. In other words, certain learning styles lead to greater positive assessment results in English while others lead to less positive results. The third step was to find out the anxiety level of these learners according to the FLCAS instrument. Finally, the fourth and final step was to find out if there was a significant link between our population's anxiety in English and their results. In other words, the least anxious learners do better on their English assessment results while the most anxious learners do less well.

According to our literature review, a learning style is a predisposition to adopt a particular learning strategy independently of the specific demands of a task (Schmeck, 1983). The learning style reflects the regularities in a student's behavior that are related to the learning that the student does. The purpose of knowing a learning style is not to make the learner a prisoner of a label, but rather to conceive and open up to new ways of learning in order to become, from the student's point of view, a more effective learner. To this end, knowing somebody's learning style can lead to greater personal empowerment and thus better academic results.

According to our review of the literature, the authors seem to have already defined, studied and found remedies for anxiety in English (as a foreign language) classrooms. Indeed, several studies have been done on how to reduce language anxiety (Alrabai, 20I5; ÇapanTekin \& AslımYetiș, 20I6) and they have proposed different solutions. Some researchers such as Kahnemann (I973) have also highlighted the fact that the more complex the task, the more stressful it becomes for students. Génard (2015) talks more specifically about negative thoughts such as past failures for example through numerical notes. It is therefore important for the teacher to build the learner's confidence. Farrell Ferris (2016) states that every teacher should regularly question his or her professional practices in order to recognize the manifestations of language anxiety in students and in order to deal with it rather than ignore it. 
Thus, according to the literature, learning styles and anxiety are both valid study factors in measuring students' assessment results in English classrooms. We therefore did not expect to discover that, for our population and therefore our research, there was no significant correlation between these three variables, namely our learners' learning styles, their language anxieties and their performance during classroom assessments. Our research therefore seems to uncover the fact that, while these hypotheses are validated with certain populations studied, our specific group of learners does not fit into the same mould as the others although anxiety is present, learning styles are defined and assessments are successful at different levels.

\section{Limitations}

Given the lack of significant correlation, the limitations of this study should be discussed. First, the number of participants is one of the limitations of this research. Indeed, given the small number of participants, it would not be appropriate to attempt to generalize the results presented here. We conducted this research with French-speaking learners studying for their higher vocational Diploma, majoring in Public Works through work-study contracts, which limits the research to a very specific group with its own intelligence styles and may not reflect a typical post-high school diploma population. The fact that the activities were adapted to the programs mentioned above also set a limit to the research, since the activities could not be compared across groups.

Second, the results of the FLCAS questionnaire could have been different if we had asked students to remain anonymous. Although we made it clear that the results of this questionnaire would have no impact on their grades or on the way the teacher would look at them, the fact that their names were recorded may hinder objectivity. Moreover, Wilkinson (20II) points out that some researchers such as Ganschow, Sparks and Javorsky (1998) have questioned the validity of the questionnaire. According to them, underlying language difficulties (which may be related to phonetics or hearing, for example) are not taken into account in the FLCAS since Horwitz et al. (1986) did not assess participants' skills.

\section{Perspectives}

Due to its limited and exploratory nature and based on our experience in the field, we propose certain avenues that invite the learner and/or teacher to reflect on learning and/or teaching 
strategies. Indeed, little research has been conducted on the combined effects of learning styles and anxiety in the same EFL class, and since some post-high school programs and continuing education and/or work-study courses are multi-level, more research is needed to address the students' needs at various levels.

In addition, it would be interesting to integrate the theory of multiple intelligences in the EFL classroom. However, before teachers apply learning models to their classrooms, they should apply them onto themselves as educators (Armstrong, 1999). Indeed, instructors must be able to diversify their teaching according to learning situations and audience. They must also be able to present and explain new learning strategies, especially to low-level audiences. They must advise learners if the choice of strategy they use is not appropriate. And finally, they must not fail to create a link between learning and everyday life. Learners must be aware that they can use their strategies in all areas and therefore they can become actors and decision-makers in their own learning.

Finally, according to data obtained from interviews with English-speaking students learning foreign languages conducted by von Wörde (2003), the factors causing anxiety are as follows: lack of comprehension, oral expression activities, pedagogical and educational practices such as test anxiety, fast pace in language class, too many topics during one semester, conversation with native speakers, and the teacher calling students in order of seating and correcting errors. It would be interesting to see how these avenues can be developed with our audience.

\section{Conclusion}

According to previous studies, some important correlates have been established with language anxiety such as those that confirm a negative relationship with foreign language achievement (AbuRabia, 2004; Kitano, 200I) due to fear of negative evaluation (Kitano 200I) and those that associate with specific learning styles (Bailey et al. 1999). These studies show that most learners feel insecure and fear negative evaluation (Casado and Dereshiwsky, 2004; Gregersen and Horwitz, 2002; Kitano, 200I). In addition, there is also some relationship between learning styles and success or failure (Jinjing, 2015) or between learning styles and language anxiety (Bailey, Daley, \& Onwuegbuzie, 1999). 
However, the lack of correlates in our study calls this into question. It should also be kept in mind, however, that our results can be attributed to the cultural influences of our population and their level of language proficiency. Thus, there are still uncertainties on this subject that need to be clarified before final conclusions can be drawn on language anxiety, learning styles and assessment results.

\section{References}

Abu-Rabia, S. (2004). Teachers' role, learners' gender differences, and FL anxiety among seventh- grade students studying English as a FL, Educational Psychology 24(5) : 7II-72I.

Alrabai, F. (2015). The influence of teachers' anxiety-reducing strategies on learners' foreign language anxiety. Innovation in Language Learning and Teaching 9 (2): 163-190. http://dx.doi.org//0.1080/1750I229.2014.890203

Armstrong T. (1999). Les intelligences multiples dans votre classe. Récupéré de http://www.thomasarmstrong.com/multiple_intelligences.htm

Ayalp, G. G., \& Özdemir, N. (2016). Relationship between Test Anxiety and Learning Styles of Architecture Undergraduates. Creative Education, 7, 364-375. http://dx.doi.org/I0.4236/ce.2016

Bailey, P., Daley C. E., \& Onwuegbuzie, A. J. (1999). Foreign language anxiety and learning style, Foreign Language Annals 32, 63-76.

Barlow, D. H. (2002). Anxiety and its disorders: The Nature and treatment of anxiety and panic. New York: Guilford Press

Barrows, J., Dunn, S., \& Lloyd, C. A. (20I3). Anxiety, self-efficacy, and college exam grades. Universal Journal of Educational Research, I(3), 204-208.

Burns, D. J. (2004). Anxiety at the time of the final exam: Relationships with expectations and performance. Journal of Education for Business, 119-124.

Butler, R. (1987). Task-involving and ego-involving properties of evaluation: Effects of different feedback conditions on motivational perceptions, interest, and performance. Journal of Educational Psychology, 79(4), 474-482. https://doi.org/I0.1037/0022-0663.79.4.474.

Çapan Tekin, S., \& AslimYetiș, V. (2016). Réduire l'anxiété langagière en production orale : jeux de rôles en FLE. Humanitas 4 (7), 73-102. http://dx.doi.org/10.20304/husbd.93239

Cano, J., \& Garton, B. L. (1994). The relationship between agriculture pre-service teachers' learning styles and performance in a methods of teaching agriculture course. Journal of Agricultural Education, 35(2), 6-10. 
Cano, J. (1999). The relationship between learning style, academic major, and academic performance of college students. Journal of Agricultural Education, 40(I), 30-37.

Casado Matt A., Dereshiwsky Mary I., (2004). Effect of educational strategies on anxiety in the second language classroom: An exploratory comparative study between U.S. and Spanish firstsemester university students, College Student Journal, 38(I), 23-36.

Cassady, J. C., \& Johnson, R. E. (2002). Cognitive test anxiety and academic performance. Contemporary Educational Psychology, 27, 270-295.

Cesur, M. O., \& Fer, S. (2009). What is validity and reliability study of learning style survey? Journal of Theory and Practice in Education, 5(2), 289-3I5.

Chapell, M. S., Blanding, Z. B., Silverstein, M. E., Takahashi, M., Newman, B., Gubi, A., \& McCann, N. (2005). Test anxiety and academic performance in under grade and graduate students. Journal of Educational Psychology, 97(2), 268-274.

Chastain, K. (1975). Affective and ability factors in second-language acquisition. Language learning, $25,|53-6|$.

Chevrier, J., Fortin, G., Leblanc, R. et Théberge, M. (2000). Problématique de la nature du style d’apprentissage. Éducation et Francophonie, 28 (I), I-I9. Récupéré de : http://www.acelf.ca/c/re

Chun-Shih, C., \& Gamon, J. A. (2002). Relationships among learning strategies, patterns, styles and achievement in web based courses. Journal of Agricultural Education, 43(4), I- I I.

Claxton, C. S., \& Ralston, Y. (1978) Learning styles: their impact on teaching and administration, (AAHE-ERIC/higher education research report no. 10). Washington: American Association for Higher Education.

Deveci, T. (2013). Adaptation of social interaction learning styles by freshman engineering students in communication courses. Yüksek Öğretim Dergisi, 3(3), I2I-I 28.

Dunn, R. (1984). Learning style: State of the science. Theory into Practice, 23(I), 10-19.

Dunn, R., DeBello, T., Brennan, P., Krimsky, J., \& Murrain, P. (198I). Learning style research define differences differently. Educational Leadership, 38, 372-375.

Dunn, R. \& Dunn, K. (1993) Teaching secondary students through their individual learning styles: practical approaches for grades 7-12. Boston: Allyn and Bacon.

Eysenck, M. W. (1979). Anxiety, learning, and memory: A reconceptualization. Journal of Research in Personality, I3(4), 363-385. https://doi.org/10.1016/0092-6566(79)9000I-I

Ferris, L. (2016). Impact de l'anxiété langagière sur l'évaluation de la production orale en continu. Education. ffdumas-0I 429938. 
Ganschow, L., \& Sparks, R., \& Javorsky, J. (1998). Foreign Language Learning Difficulties: An Historical Perspective. Journal of learning disabilities, 31 . 248-58. 10.1 I77/002221949803100304.

Gardner, R. , Lalonde, R., Moorcroft, R. \& Evers, F. (1987). Second Language Attrition: The Role of Motivation and Use. Journal of Language and Social Psychology. 6, 29-47. $10.1177 / 0261927 \times 8700600102$.

Génard, G. (2015). Ten causes of speech anxiety that create fear of public speaking. Repéré à www.genardmethod.com

Gregersen, T., \& Horwitz, E. K. (2002). Language learning and perfectionism: anxious and nonanxious language learners' reactions to their own oral performance. The Modern Language Journal, $86,562-570$

Gregorc, A. F. (1979). Learning/teaching styles: Potent forces behind them. Educational Leadership, 36(4), 234-236.

Hariri, S. A., \& Seadatee, S. A. (20l4). Self-directing skills, metacognitive beliefs, learning styles and exam anxiety in state high school students. International Journal of Education and Applied Sciences, I (7), 334-342.

Hawk, T. F., \& Shah A. J. (2007). Using learning style instruments to enhance student learning. Decision Sciences Journal of Innovative Education, 5(I), I-I9.

Honey, P., \& Mumford, A. (1986). The manual of learning styles, Maidenhead, Berkshire: Peter Honey Pub.

Horwitz, E., Horwitz, M., \& Cope, J. (1986). Foreign language classroom anxiety. The Modern Language Journal, 70(2), I25-I32. doi:I0.2307/3273।7.

Humphries, R. (20ll). Language anxiety in international student: How can it be overcome? Repéré à https://www.griffith.edu.au.

Jinjing Wang, (2015). L'impact des stratégies et styles d'apprentissage sur le sentiment de réussite ou d'échec dans l'apprentissage de langues étrangères », Recherche et pratiques pédagogiques en langues de spécialité, Vol. XXXIV Nº 2.

Josse, E. (2007). Le stress, quelques repères notionnels. Repéré à http://www.resiliencepsy.com

Joy, S. \& Kolb, D. A. (2009). Are there cultural differences in learning style? International Journal of Intercultural Relations, 33, 69-85.

Kahneman, D. (1973). Attention and effort. Englewood Cliffs: Prentice-Hall.

Kitano, K., (200I). Anxiety in the college Japanese language classroom. Modern Language Journal 85(4), 549-566. 
Kleinmank, H. H. (1977). Avoidance behavior in adult second language acquisition. Language Learning, 27, 93-I7.

Maclntyre, P. D., \& Gardner, R. C. (1994). The subtle effects of language anxiety on cognitive processing in the second language. Language Learning, 44, 283-305. http://dx.doi.org/I0.I I I I/j. I 467-I770.1994.tb0 I I03.x

Moussa, N. M. (2014). The importance of learning styles in education. Institute for Learning Styles Journal, I, 19-27.

Rana, R. A., \& Mahmood, N. (2010). The relationship between test anxiety and academic achievement. Bulletin of Education and Research, 32(2), 63-74.

Onwuegbuzie, A. J., Bailey, P., \& Daley, C. E. (1999). Factors associated with foreign language anxiety. Applied Psycholinguistics, 20(2), 2 17-239. https://doi.org/I0.10I7/S0 I 427I 6499002039

Rana, R. A., \& Mahmood, N. (2010). The relationship between test anxiety and academic achievement. Bulletin of Education and Research, 32(2), 63-74.

Schmeck, R. R. (1983). Learning styles of college students. Dans Rona F. Dillon \& Ronald R. Schmeck (Ed.) Individual differences in Cognition, volume I, New-York: Academic Press, Pp. 233-279.

Théberge, M., Chevrier, J., Fortin, G. \& Leblanc, R. (2000). Une utilisation du style d'apprentissage dans un contexte de formation à l'enseignement. Éducation et Francophonie, 28 (I), I0II I7.Récupéré de: http://www.acelf.ca/c/revue/pdf/EF-XXVIIInol-Une-utilisation-du-style-dapprentissage.pdf

Von Der Embse, N. P., Schultz, B. K., \& Draughn, J. D. (20I5). Readying students to test: The influence of fear and efficacy appeals on anxiety and test performance. School Psychology International, 36(6), 620-637.

Von Wörde, R. (2003) Students' perspectives on foreign language anxiety. Inquiry (e-journal) 8(I), I15.

Wilkinson, J. (20I I). L'anxiété langagière chez les locuteurs d'anglais de niveau universitaire selon le programme d'apprentissage du français langue seconde préalablement suivi. Mémoire de Master de la Faculté des études supérieurs de I'Université Laval Québec, Linguistique et traduction.

Williams, K. (I99I) Anxiety and formal second/foreign language learning. RELC Journal: A Journal of Language Teaching and Research in Southeast Asia, 22(2), 19-28.

Young, D. J. (1986). The relationship between anxiety and foreign language oral proficiency ratings, Foreign Language Annals, 19, p. 439-445.

Young, D. J. (1990). An investigation of students' perspectives on anxiety and speaking. Foreign Language Annals, 23, 539-567. 
Zaborowska, E. (2003). Validation du Foreign language class Anxiety Scale dans la détermination des facteurs anxiogènes de l'anglais langue seconde. Mémoire de Master de l'Université du Québec à Montréal, concentration didactique.

Zheng, Y. (2008). Anxiety and second/foreign language learning revisited. Canadian Journal for New Scholars in Education. I ( I), 345-354. 